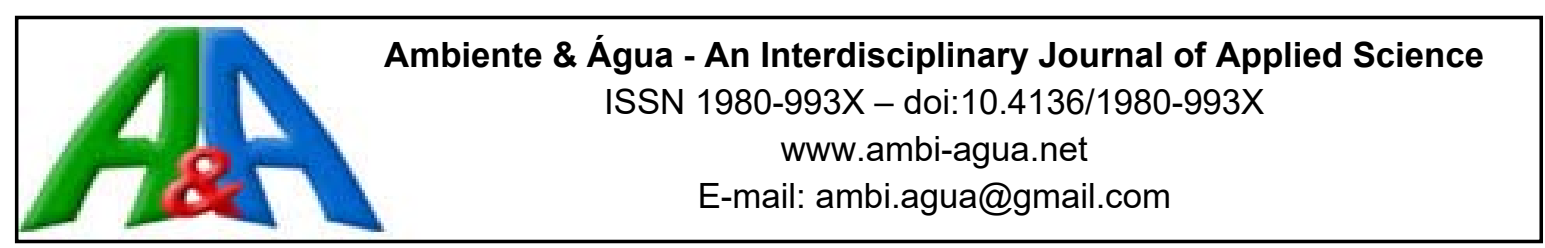

\title{
Analysis of the role of the sanitary landfill in waste management strategies based upon a review of lab leaching tests and new tools to evaluate leachate production
}

\author{
doi:10.4136/ambi-agua.2096 \\ Received: 15 Feb. 2017; Accepted: 10 May 2017

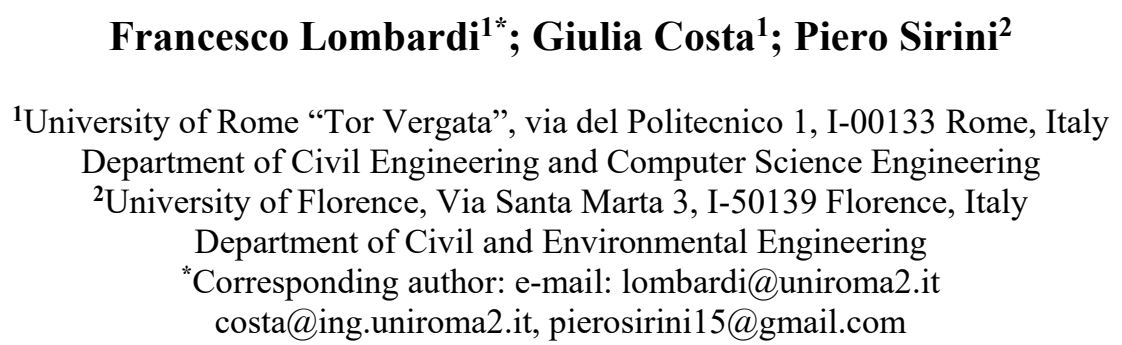

\begin{abstract}
This paper reviews the role of sanitary landfills in current and future waste management strategies based upon the principles and the goals established by the European Framework Directive on Waste (2008/98/EC). Specific reference is made to studies of our research group regarding new tools developed to evaluate leachate production, taking into account the different characteristics of municipal solid waste (MSW). Laboratory leaching tests and a methodology proposed to interpret the results are described and discussed, as well as tools developed to estimate landfill leachate production. Residual flows produced by mechanical-biological treatment (MBT) plants, mainly Solid Recovered Fuel (SRF) and Stabilized Organic Waste (SOW), incineration and composting plants are considered in particular. Experimental results showed that the most suitable end-uses or disposal options for the outputs of waste treatment plants are site-specific and should be defined on the basis of a detailed characterization. The application of the model developed to assess landfill leachate production showed a very good agreement with field data.
\end{abstract}

Keywords: biological-hydrological processes, leaching tests, metals.

\section{O Papel do aterro sanitário na gestão do lixo com base em uma revisão de novos instrumentos para avaliar a produção de chorume no mesmo aterro}

\section{RESUMO}

Este artigo revisa o papel dos aterros sanitários nas estratégias atuais e futuras de gestão de resíduos com base nos princípios e objetivos estabelecidos na diretiva europeia sobre o lixo 2008/98/EC. O texto baseia-se especificamente nos estudos de nosso grupo de pesquisa sobre novas ferramentas desenvolvidas para avaliar a produção de lixiviados, levando-se em consideração as diferentes características dos resíduos sólidos urbanos (RSU). Os testes de lixiviação em laboratório e uma metodologia proposta para interpretar os resultados são descritos e discutidos, bem como foram desenvolvidas ferramentas para estimar a produção de 
lixiviados em aterro. Consideram-se, em particular, os fluxos residuais produzidos por instalações de tratamento mecânico-biológico (MBT, sigla em inglês), principalmente as instalações de incineração e compostagem de resíduos sólidos recuperados (SRF, sigla em inglês) e de resíduos orgânicos estabilizados (SOW, sigla em inglês). Os resultados experimentais mostraram que as utilizações finais ou as opções de eliminação mais adequadas para os materiais das estações de tratamento de resíduos são específicas do local e devem ser definidas com base numa caracterização pormenorizada. A aplicação do modelo desenvolvido para avaliar a produção de lixiviados em aterro mostrou um ótimo acordo entre os resultados do modelo com os dados de campo.

Palavras-chave: metais Pesados, processo biológico-hidrológico, teste em coluna.

\section{INTRODUCTION}

The European Waste Framework Directive (2008/98/EC) establishes that the first objective of any waste policy should be to minimize the negative effects on human health and the environment related to the generation and management of waste. Waste policy should also aim at reducing the use of natural resources and favor the application of the waste hierarchy concept, which establishes the following order of priority with regard to waste management strategies: prevention, preparing for re-use, recycling, other recovery (e.g. energy recovery) and disposal. Member States shall ensure that, where recovery is not undertaken, waste undergoes safe disposal operations (e.g. in a sanitary landfill) which meet the protection of human health and the environment.

In this view, the management practices that are generally adopted to achieve these objectives are reuse and recycling of specific waste fractions through source separation, other forms of material recovery from commingled waste such as mechanical separation and energy recovery from the dry and/or wet waste fractions, mainly by thermal treatment. Final disposal of waste in sanitary landfills is considered the least preferred option, which should be applied only to the residual fractions of prior treatment stages, when further recovery is deemed technically and economically unfeasible (Lombardi et al., 2010).

Source separation of selected fractions of MSW is the main and indispensable strategy that allows material recovery. Therefore, as long as it is technically and economically feasible, the objective of material recovery should be pursued at the costs that the community is willing to pay. However, depending on the type of collection strategy adopted, source separation percentages cannot realistically exceed certain maximum percentages, particularly when they are addressed at selecting waste fractions that can actually be recycled. Hence, in order to follow the EU waste management protocol, i.e. give priority to material recovery and recycling from waste, source separation of recyclable fractions from selected production activities should be preferred instead of establishing increasingly higher (and impractical) overall source separation objectives (Lombardi et al., 2010).

The waste management practices currently adopted by single member countries differ significantly. Countries such as Germany, Denmark, The Netherlands, Sweden and Belgium landfill less than $1.4 \%$ of the produced MSW, incinerating over $35 \%$ and recovering the rest with different strategies (including mechanical or manual sorting, composting, anaerobic digestion, etc.). In most of the recent EU member countries, as well as Spain and Greece, instead, sanitary landfilling is still the most-adopted waste management strategy $(>50 \%)$.

Vehlow et al. (2007) have shown that EU member states that extensively practice material recovery (including composting) also incinerate a major part of their residual waste. The correlation between high recycling rates and the adoption of waste-to-energy treatments for 
commingled residual waste was also evidenced in other studies (i.e.: Castaldi and Themelis, 2010).

Italy, in compliance with the EU's waste policy, has set increasing annual separation objectives in the last few years with the goal of enhancing source separation of selected MSW fractions. In addition, the European Landfill Directive (1999/31/EC) requires Member States to decrease the amount of biodegradable municipal waste (BMW) going to landfills and to this aim has set specific reduction targets. The anaerobic biodegradation processes occurring during the disposal of this waste fraction is in fact the main cause of greenhouse gas emissions and leachate production with a high load of contaminants.

Furthermore, national waste acceptance criteria have been recently issued in compliance with the principles stated by the EU Landfill Directive and specific limit values established by the EU Council Decision 2003/33/EC. These acceptance criteria are mainly based on the results of standard leaching tests, such as the EN 12457 tests, and regard eluate concentrations of different kinds of contaminants, including metals, metalloids, soluble salts and Dissolved Organic Carbon (DOC).

Thus, regarding the management of the residual commingled waste obtained after source separation of selected MSW fractions, pre-treatment strategies aimed at achieving energy recovery and/or improving the environmental characteristics of the waste prior to its final disposal are being increasingly implemented (Lombardi et al., 2010).

The selection of the treatment and/or pre-treatment processes to apply to commingled residual waste must be made considering the final characteristics of the end products, so as to maximize material and energy recovery from every material flow, in accordance with the requirements of law (Italian Legislative Decree n. 36 13/01/2003).

Two of the main strategies currently pursued in Italy for managing residual MSW are Mechanical Biological Treatment (MBT) and thermal treatment (incineration or energy recovery). In 2015 , over $36 \%$ and $21 \%$ of residual MSW was treated in these types of facilities, respectively (ISPRA, 2016). MSW management strategies, however, are established at a regional level, and hence significant differences can be found from one geographical area to another.

Mechanical-biological treatment (MBT) plants treat residual MSW after source separation, with the aim of minimizing the environmental impacts associated with the landfilling of the residues and to obtain potentially reusable or recyclable materials (Bayard et al., 2010; Di Lonardo et al., 2012). MBT involves a combination of mechanical processes (shredding, size, density and magnetic separation, densification, etc.) and biological treatment (aerobic or anaerobic degradation) of the mechanically separated organic fraction. An important objective for MBT plants is to achieve effective material flow management of residual waste that involves extracting homogeneous fractions for material or energy recovery, along with the aim of minimizing the environmental impacts associated with the landfilling of residues (Cossu et al., 2003; De Gioannis et al., 2009; Di Lonardo et al., 2012). The characterization of MBT input and outputs flows is needed to evaluate their quality and to determine the effectiveness of MBT plants to produce materials that can be utilized for material or energy recovery. Therefore, the most suitable end-uses or disposal strategies for MBT outputs are site-specific and should be defined on the basis of a detailed characterization to identify specific quality classes with reference to appropriate technical standards, e.g. Solid Recovered Fuel regulations (Di Lonardo et al., 2012).

As for the management of the humid fraction of MSW, two main treatment options may be identified: treatment of source-separated organic waste, that gives the opportunity to reuse the stabilized or digested end products (i.e. compost in the case of aerobic processes and solid digestate in the case of anaerobic processes); and treatment of residual MSW separated in MBT plants. This latter material is generally treated by aerobic biodegradation processes and 
disposed of in landfills along with processing scraps or employed as daily cover material during landfilling. Biological treatment of the humid fractions separated in MBT plants was first applied as a MSW pre-treatment strategy prior to disposal in order to reduce the biodegradable matter content of the waste going to landfills. Therefore, the quality of the output of the treatment was not specifically monitored. Recently, interest in potential recycling or recovery options for the bio-stabilized waste produced in MBT plants is increasing, especially considering the large amounts of this waste stream being produced in specific areas such as Central and Southern Italy in line with efforts to divert waste from landfills (Di Lonardo et al., 2012). Thus, in the last few years, several studies were conducted to assess the fundamental characteristics of MBT waste such as physical-chemical properties (e.g. volatile solids, total and dissolved organic carbon, heavy metals content) and biological characteristics (e.g. respiration activity, biomethane potential emissions) (Farrel and Jones, 2009; Di Lonardo et al., 2015a; 2015b; Pantini et al., 2015a; 2015b). Interest is very strong in places such as Rome where $40-50 \%$ by weight of the residual MSW is comprised of fractions containing biodegradable waste, as observed by several studies of material composition in the years 2006-2013 (Di Lonardo et al., 2016).

MBT may be applied with or without refuse-derived fuel (RDF) production, whereas, depending on the type of treated waste, three main processes may be identified for energy recovery from MSW: direct incineration of residual MSW; thermal treatment (mainly incineration) of the dry fraction of the residual MSW, separated at the incinerator facility or in dedicated sorting plants; and thermal treatment (mainly incineration) of RDF produced at MBT facilities (Velis et al., 2012; Lombardi et al., 2010).

Di Lonardo et al. (2016) showed that, in order to meet RDF requirements regarding the Net Calorific Value (NCV) limit ( $\left.\geq 15 \mathrm{MJ} \mathrm{kg}^{-1}\right)$, after the first size-separation step, in which the coarse (dry) fraction is separated from the fine (wet biodegradable) one, the former fraction must undergo air classification. This treatment is aimed at producing a material flow with an increased content of paper and plastics (light materials), and thus higher NCV. As a consequence, heavy rejects are produced. As for the wet fraction, after the aerobic stabilization treatment carried out in the MBT plant, stabilization rejects are separated by screening from the final bio-stabilized waste. Both heavy and stabilization rejects (reject flows) are characterized by a lower NCV, and are typically disposed of in a sanitary landfill. It should be noted that the Italian Legislative Decree 205/2010 abrogated the definition of refuse derived fuel (RDF) and its classification methods and replaced it with those referring to solid recovered fuel (SRF). In consideration of the new classification, the reject flows combined with RDF could be now classified as SRF and employed in waste to energy plants or employed as fuel in industrial plants (e.g. cement kilns). Considering data for the city of Rome, thermal treatment of the reject flows may allow the city to more than double (from $26 \%$ to $59 \%$ ) the amount of waste employed for energy recovery and reduce by about 33\% the amount of waste to be landfilled (Di Lonardo et al., 2016).

Regarding other types of residues from MSW treatment, Bottom Ash (BA), the most abundant solid residue generated by thermal waste treatment, accounting for 10-30\% of input waste mass, depending on the specific type of technology and operating conditions applied, is another material which is mostly disposed of in landfills in many EU Countries. As BA exhibits similar technical properties to those of natural aggregates, in recent years several efforts have been made to encourage the recycling of BA as a secondary material in construction applications. This may result in two main beneficial effects: (1) a decrease in waste landfilling, which presents significant environmental impacts including land use; (2) a reduction in the consumption of virgin raw materials. However, the limiting factor for utilizing this type of residue is related to its potential release of contaminants upon contact with water (i.e. its 
leaching behavior) (Hjelmar et al., 2010; Di Gianfilippo et al., 2016a; 2016b).

Finally, on the basis of the above-mentioned potential recovery options for MSW treatment residues and considering that the disposal of waste in sanitary landfills should be the least preferred option according to the EU's Waste Framework Directive, it is expected that now, and even more in the next few years, the characteristics of landfilled waste and, as a consequence, those of leachate and biogas, will differ in terms of quality and quantity from the data now available, which is mainly related to MSW disposal. For this reason, it is important that researchers define and test new models and/or tools (Schroeder et al, 1994; Berger, 2002; De Cortázar et al., 2002a; 2002b; Jang et al., 2002; Pantini et al., 2014; Yang et al., 2015) for evaluating the quality of waste treatment residues in order to determine if it is possible to divert them from landfills and at the same time assess leachate and biogas production in landfills receiving only waste-treatment residues.

The next paragraphs provide a short review of the main results of studies performed by our group on these topics, focusing in particular on the assessment of the leaching behavior of stabilized biodegradable waste from Mechanical Biological Treatment to analyze its potential for landfill diversion and landfill leachate simulation models based on the Landfill Water Balance model (LWB) implemented in the Leachate Assessment Screening Tool (LAST).

\section{STUDIES OF THE LEACHING BEHAVIOR OF MBT-STABILIZED BIODEGRADABLE WASTE}

Interest in the possibility of recovering stabilized biodegradable waste from MBT plants, as well BA from waste to energy plants (Di Gianfilippo et al., 2016a; 2016b) is related to the large amounts that are now being produced in countries such as Italy, for example. The study of the leaching behavior of these waste flows is essential to establish their recycling or reuse potential and also to estimate the composition of the leachate they may produce in a sanitary landfill disposal scenario.

Generally, two distinct approaches may be adopted in order to assess the leaching behavior of a waste material: lab-scale experiments which may be applied employing different testing procedures (e.g. batch tests or up-flow column percolation tests) and a sampling campaign carried out at full scale in a landfill site. With regard to lab scale leaching tests, the static batch leaching test (UNI EN 12457 series) is the most widely used method for assessing the potential release of pollutants from a wide variety of solids and waste materials. However, single batch extraction tests give an indication of metal leachability under specific experimental conditions and do not allow an extrapolation of long-term behavior. Hence, these tests are generally used as a simple tool for compliance or quality control. In order to overcome this limitation, in the last few years new methodologies, such as multiple-batch extraction tests, $\mathrm{pH}$ dependent and up-flow column percolation tests, were developed. Nowadays, column percolation tests are preferred as they are able to simulate water flow through the material and to assess leaching behavior over an extended period. In this view, column experiments may better resemble natural field conditions with respect to other types of laboratory tests. Nevertheless, attention must be paid to the interpretation of the data obtained from these tests, especially if the experimental results are employed to predict the release of potential contaminants over time (Pantini et al., 2015a).

The leaching behavior of stabilized biodegradable waste was specifically analyzed for samples taken from an Italian MBT plant during three different campaigns in order to account for seasonal variation of waste characteristics (Pantini et al., 2015a). The results of several batch and up-flow percolation tests showed that, even though samples were characterized by a relatively high content of metals and metalloids (Table 1), only a limited amount was soluble 
and thus bioavailable. The amounts released were generally lower than $5 \%$ of the total content, with only the exception of dissolved organic carbon (DOC, Figure 1, a), Zn, Ni and Co, with release percentages up to $20 \%$. The information provided by the different tests also allowed the highlighting of some key factors governing the kinetics of DOC and metals release from this type of material (Pantini et al., 2015a). In particular, results of up-flow column percolation tests showed that metals such as $\mathrm{Cr}$ (Figure 1, b), $\mathrm{Mg}, \mathrm{Ni}$ and $\mathrm{Zn}$ followed the leaching trend of DOC, suggesting that these elements were mainly released as organo-compounds (Pantini et al., 2015a). Specifically, a linear correlation between leachate concentrations of DOC and metals was observed for $\mathrm{Cr}\left(\mathrm{R}^{2}>0.8\right)$ (see Figure $\left.1, \mathrm{c}\right)$, Ni and $\mathrm{Zn}\left(\mathrm{R}^{2}>0.94\right)$. Thus, combining the results of batch and up-flow column percolation tests, partition coefficients between metals and DOC were derived (Pantini et al., 2015a).

Table 1. Bulk chemical composition and organic matter content of the analyzed samples of stabilized biodegradable waste from an MBT plant (Reprinted from Pantini et al. 2015a with permission from Elsevier).

\begin{tabular}{|c|c|c|c|}
\hline Parameter & MBT 1 & MBT 2 & MBT 3 \\
\hline \multicolumn{4}{|c|}{ Macro-constituents ( $\left.\mathrm{g} \mathrm{kg}^{-1} \mathrm{DM}\right)$} \\
\hline $\mathrm{Al}$ & $10.6 \pm 2.3$ & $14.2 \pm 0.11$ & $4.1 \pm 0.1$ \\
\hline $\mathrm{Ca}$ & $62.7 \pm 4.9$ & $72.7 \pm 14.5$ & $53.8 \pm 2.0$ \\
\hline $\mathrm{Fe}$ & $9.9 \pm 0.5$ & $9.3 \pm 0.5$ & $8.0 \pm 0.2$ \\
\hline $\mathrm{K}$ & $8.9 \pm 0.6$ & $10.7 \pm 0.1$ & $7.4 \pm 0.3$ \\
\hline $\mathrm{Mg}$ & $4.1 \pm 0.0$ & $3.9 \pm 0.1$ & $4.1 \pm 0.1$ \\
\hline $\mathrm{Na}$ & $5.7 \pm 0.3$ & $7.5 \pm 1.3$ & $5.6 \pm 0.1$ \\
\hline \multicolumn{4}{|c|}{ Trace elements (mg kg-1 DM) } \\
\hline $\mathrm{Ba}$ & $307 \pm 56$ & $383 \pm 32$ & $305 \pm 17$ \\
\hline $\mathrm{Co}$ & $3.3 \pm 0.7$ & $2.4 \pm 0.1$ & $1.6 \pm 0.3$ \\
\hline $\mathrm{Cr}$ & $18.8 \pm 3.9$ & $30.3 \pm 15.2$ & $29.3 \pm 1.3$ \\
\hline $\mathrm{Cu}$ & $154 \pm 6$ & $172 \pm 110$ & $108 \pm 18$ \\
\hline $\mathrm{Li}$ & $3.8 \pm 0.5$ & $5.4 \pm 0.4$ & $5.1 \pm 0.2$ \\
\hline $\mathrm{Mn}$ & $201 \pm 5$ & $212 \pm 9$ & $176 \pm 16$ \\
\hline Mo & $2.2 \pm 0.1$ & $1.7 \pm 0.1$ & $2.3 \pm 0.1$ \\
\hline $\mathrm{Ni}$ & $17.9 \pm 2.6$ & $15.7 \pm 0.4$ & $24.2 \pm 1.2$ \\
\hline $\mathrm{Pb}$ & $390 \pm 67$ & $350 \pm 120$ & $251 \pm 16$ \\
\hline $\mathrm{V}$ & $18.8 \pm 2.4$ & $21.7 \pm 1.1$ & $18.2 \pm 0.7$ \\
\hline $\mathrm{Zn}$ & $322 \pm 21$ & $370 \pm 7$ & $307 \pm 12$ \\
\hline TOC (\%DM) & $28.1 \pm 0.1$ & $27.0 \pm 0.5$ & $26.9 \pm 1.3$ \\
\hline VS (\%DM) & $56.3 \pm 0.7$ & $54.2 \pm 1.6$ & $53.3 \pm 1.3$ \\
\hline
\end{tabular}




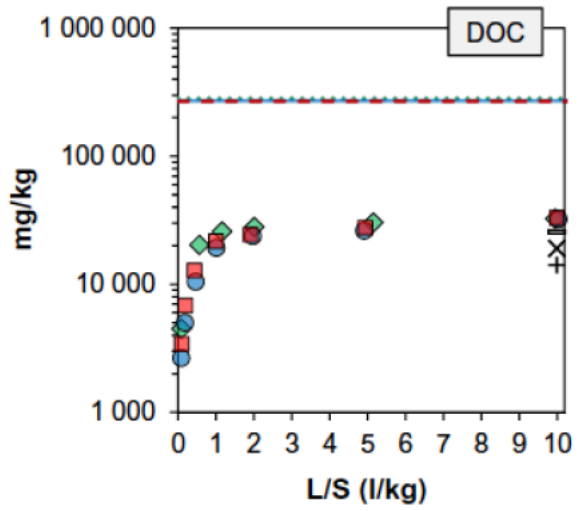

(a)

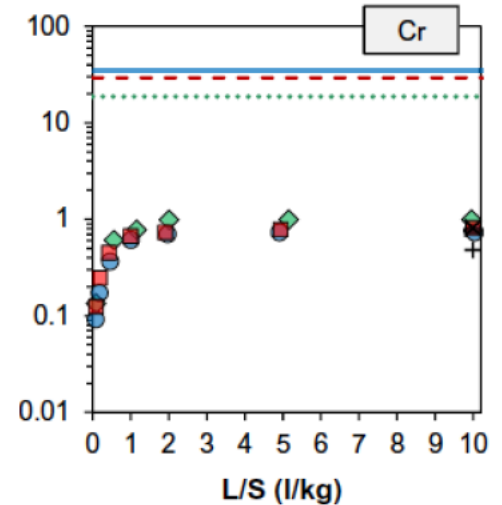

(b)

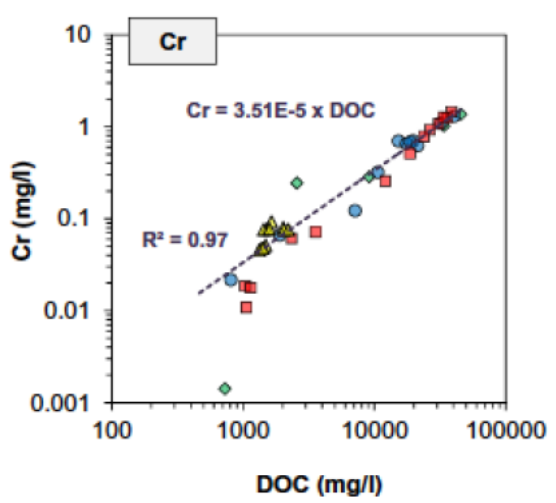

(c)

$\diamond \mathrm{MBT} 1$ - MBT 2 - MBT $3 \ldots \ldots$ TC 1 - TC $2--\mathrm{TC}_{3}-\mathrm{ENV} 1 \times \mathrm{ENV} 2+\mathrm{ENV} 3$

Legend: Total content (lines) and cumulative element release (dots) measured in the column tests MBT 1 (green), MBT 2 (blue) and MBT 3 (red). Black symbols represent constituent concentrations measured in batch leaching tests conducted with $0.001 \mathrm{M} \mathrm{CaCl}_{2}$ solution $(\mathrm{ENV} \mathrm{1,} \mathrm{2,} \mathrm{3).} \mathrm{a)} \mathrm{DOC}$

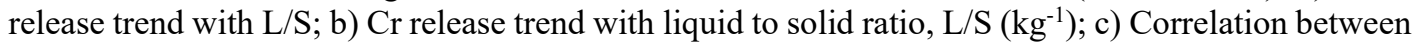
$\mathrm{Cr}$ and DOC leaching.

Figure 1. Main results of leaching column tests carried out on stabilized biodegradable waste produced in an Italian MBT plant. (Reprinted from Pantini et al. (2015a) with permission from Elsevier).

These data, were coupled with a simplified screening model for Metal release ( $\mathrm{M}_{\mathrm{cum}}(\mathrm{Me})$ in $\mathrm{mg} \mathrm{kg}^{-1}$ ) to DOC (Pantini et al., 2015a; Equation 1):

$$
\left\{\begin{array}{c}
M_{\text {cum }(M e)}=\left(\frac{L}{S} \cdot \frac{T O C}{K_{d}}\right) \cdot K_{D O C, M e} \text { for } \frac{L}{S} \leq \frac{L}{S^{*}} \\
M_{\text {cum }(M e)}=\left(\frac{L}{S^{*}} \cdot \frac{T O C}{K_{d}}+2 \cdot \frac{T O C}{h_{c}} \cdot \sqrt{\left(\frac{D \times\left(t-t^{*}\right)}{\pi}\right)}\right) \cdot K_{D O C, M e} \text { for } \frac{L}{S}>\frac{L}{S^{*}}
\end{array}\right.
$$

where:

$\mathbf{L} / \mathbf{S}\left(\mathrm{kg}^{-1}\right)$ is the liquid to solid ratio,

TOC the total organic carbon content,

$\mathbf{K}_{\mathbf{d}}$ the partition coefficient between TOC and DOC (i.e. DOC $=\mathrm{TOC} / \mathrm{K}_{\mathrm{d}}$ ) and

$\mathbf{K}_{\mathbf{D O C}, M e}$ the empirical partition coefficient between metal (Me) and DOC (e.g. the one fro $\mathrm{Cr}$ is reported in Figure 1, c),

$\mathbf{L} / \mathbf{S}^{*}$ and $\mathbf{t}^{*}$ are the critical liquid to solid ratio and time, respectively, above which the mass release switches to a mass transfer-controlled scenario,

D is the diffusivity of the constituent in water $\left(\mathrm{m}^{2} \mathrm{~s}^{-1}\right)$ and

$\mathbf{h}_{\mathbf{c}}$ the column height (m).

Figure 2 reports a comparison of the cumulative mass release of chromium measured in the column test and the values predicted by the model (Pantini et al., 2015a).

The obtained results clearly show that, at least for this metal, the simplified approach proposed in Equation 1 allows a good prediction of metal release from the column test. However, it should be noted that the model presented here does not account for long-term processes, such as geochemical and biological processes, which are likely to occur in a landfill and can influence DOC release, the form of soluble organic matter and its ability to bind metals.

\section{IPABH}




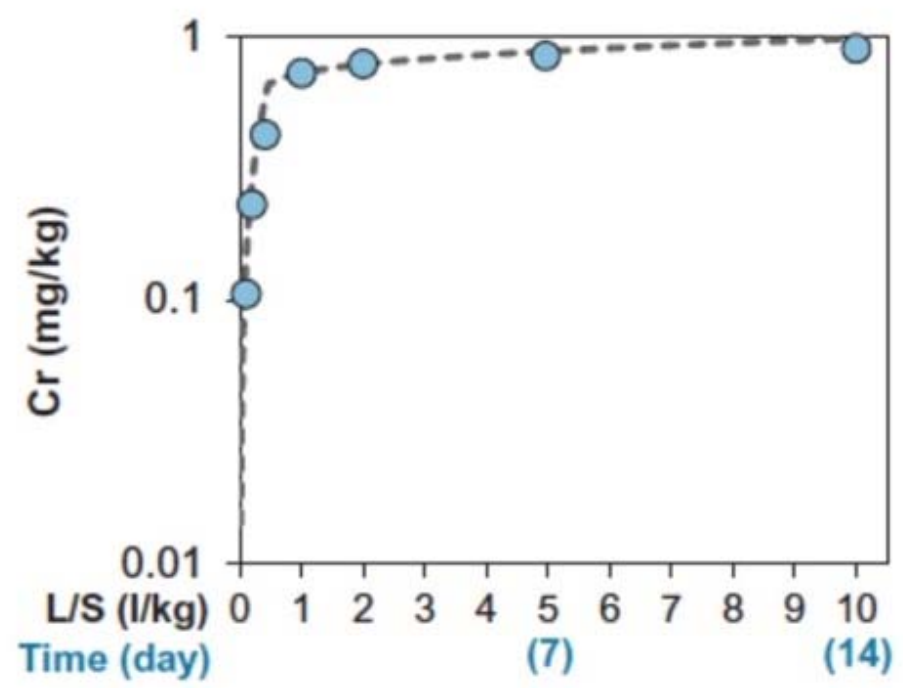

Figure 2. Cumulative mass release of $\mathrm{Cr}$ from the column test (blue circles) and modelled trend (dashed line) (Reprinted from Pantini et al. (2015a) with permission from Elsevier).

The influence of the duration of the bio-stabilization process is highlighted in two studies (Di Lonardo et al., 2015a; 2015b). The first study (Di Lonardo et al., 2015a) showed that an additional ripening process after the 28-day stabilization treatment improved the quality of the product, which showed a much higher biological stability. In addition, at the end of the ripening post-treatment the release of metals $(\mathrm{Co}, \mathrm{Cr}, \mathrm{Cu}, \mathrm{Ni}, \mathrm{Pb}$ and $\mathrm{Zn})$ from the waste decreased significantly compared to the product of the 4-week bio-stabilization process, showing also that metals were mainly bound to solid organic matter. The study thus suggests the need to extend and optimize the biological treatment applied in MBT facilities, in view of possibly recovering the output instead of landfilling it. The second study (Di Lonardo et al., 2015b) confirmed that stabilized bio-waste did not prove to be biologically stable after 4 weeks of the stabilization process, presenting a dynamic respiration index well above $1,000 \mathrm{mg} \mathrm{O}_{2} \mathrm{~kg} \mathrm{VS}^{-1} \mathrm{~h}^{-1}$. The metal content $(\mathrm{Cd}, \mathrm{Cr}, \mathrm{Cu}, \mathrm{Ni}, \mathrm{Pb}, \mathrm{Zn})$ fulfilled the requirements for utilization, but instead the leaching of these elements was quite high and not compliant with Italian regulatory limits for waste recovery. In order to improve the quality of this waste treatment residue, operating conditions of the biological process should also be modified, such as the water content of the material, since the output material presented a moisture content of $19.7 \%$, quite lower than the content recommended for optimizing aerobic biodegradation $(40 \%)$. The study also showed that fractions with a particle size greater than $10 \mathrm{~mm}$, which present a high content of impurities and heavy metals, should be separated to improve the quality of the product. The finer fraction $(<10 \mathrm{~mm})$ after effective bio-stabilization could potentially be recovered in environmental remediation activities, whereas the coarser fractions $(\geq 10 \mathrm{~mm}$ ) could be sent to waste-to-energy plants, given their significant content of high calorific value materials and compliance with the requirements for solid recovered fuels.

\section{SIMULATION MODELS BASED ON THE WATER BALANCE METHOD "LWB" IMPLEMENTED IN THE "LAST" TOOL}

In the last decades, several mathematical models have been developed to simulate the generation and transport of leachate in landfills. The most widely used package is the 
Hydrologic Evaluation of Landfill Performance, HELP (Schroeder et al., 1994), even though recently its use has been questioned, since a number of limitations have been detected (Pantini et al, 2014).

In order to overcome these limitations, several integrated models have been developed to take into account both leachate and gas generation due to biological transformation of organic matter, simulating jointly hydrological and degradation phenomena. These models differ by the underlying assumptions and the conditions for which they can be applied. Among these, the Landfill Water Balance model (LWB) (Pantini et al, 2014), based on analytical and empirical equations, allows for the prediction of leachate volume produced during the entire life of a landfill, from the operational stages to the aftercare period, taking into account of all the principal factors and processes that affect the water balance. The main features of the model are reported in Figure 3. The detailed description and its applications are shown in Pantini et al. (2014) and Grugnaletti et al. (2016).

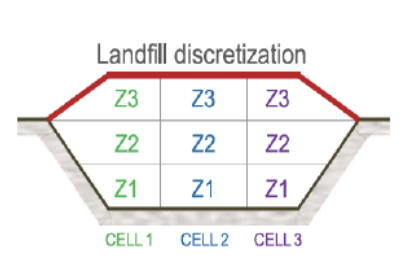

$$
\text { I }
$$

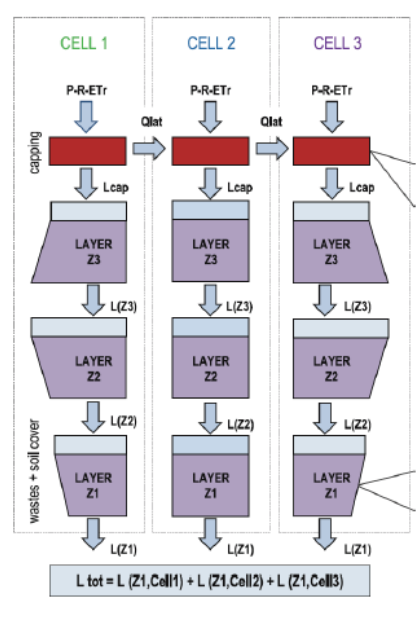

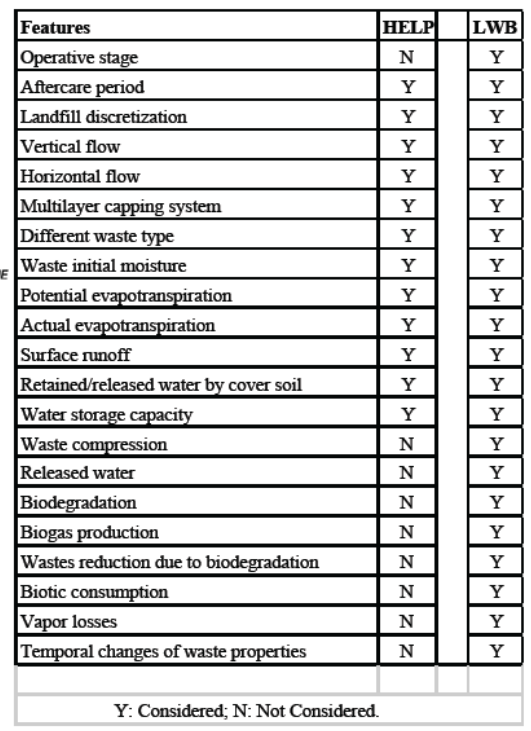

Figure 3. Main features of the LWB mode for estimating landfill leachate prediction. (Reprinted from Pantini et al. (2014) with permission from Springer Science+Business Media).

The developed model allows the simulation of filling operations of an active landfill by discretizing the whole system in different hydraulically interconnected and customizable cells. In addition, the aftercare periods can also be simulated by introducing information about the capping system. It accounts for the progressive variation of landfill geometry, during the operational stages, as well as temporal changes of waste hydraulic and physico-mechanical properties that may occur during disposal. These features may lead to a more realistic estimation of leachate production over time. The code reproduces wastes disposal and management methods as the overall landfill system is discretized in different elements indicated as cells. For each cell, the number of layers $\mathrm{Zj}$, the surface area, the thickness, the progressive time of layer disposal, the hydrological properties, and the type of landfilled waste (e.g., municipal solid wastes, bio-stabilized organic fraction, mechanical-biological treatment scraps, etc.) can be defined. For post-closure management, further information related to the capping system (i.e., vegetation and soil cover, lateral drain layers, low permeability barrier soils and geomembrane liners) can be introduced. For each layer, the proposed model applies a water balance accounting for all of the main parameters and processes affecting leachate production (e.g., biodegradation, gas production and biotic consumption, waste aging and compaction), as well as their temporal variation by applying simple empirical and analytical equations. In order to 
assess the influence of these parameters and processes on leachate estimation, several simulations assuming different scenarios were carried out.

The results obtained applying this model for different municipal solid waste (MSW) properties were compared with those achieved employing the HELP model which neglects waste compaction and biodegradation processes. The results showed that waste compaction phenomena affect leachate production to a large extent during the operational stages of the landfill and that neglecting these processes could lead to underestimations of up to one order of magnitude. Also, biodegradation of the organic matter content of the waste may result. This may influence the water storage capacity of the waste and lead to a 2-3 times greater leachate production (Pantini et al., 2014). The predicted values, obtained applying the LWB model, showed a quite good agreement with the leachate resulting from the final collection pipes of a full-scale landfill (Pantini et al., 2014).

The model was implemented in a tool named the "Leachate Assessment Screening Tool" (LAST) that is equipped with a user-friendly interface allowing users to easily handle the input and output data (Grugnaletti et al., 2016). This tool was applied to four Italian landfill sites in the operational management (i.e. filling) stage. The results revealed that when literature values were assumed for the unknown input parameters, the model provided a rough estimation of the leachate production measured in the field (Grugnaletti et al., 2016). In this case, indeed, the deviations between observed and predicted data appeared in some cases to be significant. Conversely, by performing a preliminary calibration for some of the unknown input parameters (e.g. initial moisture content of the waste, compaction index), in nearly all cases the model output was significantly more similar to field data (Grugnaletti et al., 2016). Although these results indicated the potential capability of the water balance model to estimate leachate production at landfill sites, they also showed the intrinsic limitation of a deterministic approach to accurately predict leachate production over time. Indeed, parameters such as the initial water content of the incoming waste and the compaction index, that have a great influence on leachate production, may exhibit a temporal variation due to seasonal changes in weather conditions (e.g. rainfall, air humidity), as well as the seasonal variability of the amount and type of the specific waste fractions produced (e.g. yard waste, food, plastics) that make their prediction quite complicated. In this sense, we believe that a tool such as LAST, which requires a limited number of unknown parameters, may be employed more easily to quantify these uncertainties with respect to other more sophisticated models (Grugnaletti et al., 2016).

\section{CONCLUSIONS}

Reuse and recycling of specific waste fractions through source separation and other forms of material recovery from commingled waste, such as mechanical separation and energy recovery from the dry and/or wet waste fractions, have been determined by European Council regulation to be priorities for MSW management. Final disposal of waste in sanitary landfills is thus considered the least-preferred option, which should be applied only to residual fractions of prior treatment stages, when further recovery is deemed technically and economically unfeasible. This concept has great consequences on the types and amounts of waste fractions that will be disposed of in landfills soon, as well as on the potential environmental impacts of landfilling. Therefore, research efforts in this field are aimed at defining new criteria, studies, models and tools to help regulators in making correct assumptions and decisions, as well as stakeholders in general for correctly evaluating the best waste management options with regard to human health and environmental protection. This paper reported the results of studies performed by our group to assess the properties of the main by-products of waste treatment processes based on experimental data, in view of recycling or landfill disposal. In addition, 
tools developed to evaluate landfill leachate production are presented and discussed, considering the different characteristics of residual waste with respect to raw MSW. With regard to landfill leachate production, the results obtained by applying the developed tools showed a quite good agreement with field measurements. Further investigations are still necessary to further determine the behavior of the different residues produced by waste treatment plants in order to evaluate their potential impacts in landfills and to assess if and how they may be recycled or employed for energy recovery.

\section{REFERENCES}

BAYARD. R.; DE ARAÚJO MORAIS, J.; DUCOM, G.; ACHOUR, F.; ROUEZ M.; GOURDON, R. Assessment of the effectiveness of an industrial unit of mechanicalbiological treatment of municipal solid waste. Journal of Hazardous Materials, v. 175, p. 23-32, 2010. https://doi.org/10.1016/j.jhazmat.2009.10.049

BERGER, K. Potential and limitations of applying HELP model for surface covers. Practice Periodical of Hazardous, Toxic, and Radioactive Waste Management, v. 6, n. 3, p. 192-203, 2002. http://dx.doi.org/10.1061/(ASCE)1090-025X(2002)6:3(192)

CASTALDI, M. J.; THEMELIS, N. J. The case for increasing the global capacity for waste to energy (WTE). Waste and Biomass Valorization, v. 1, n. 1, p. 91-105, 2010. https://doi.org/10.1007/s12649-010-9010-1

COSSU, R.; RAGA, R.; ROSSETTI, D. The PAF model: an integrated approach for landfill sustainability. Waste Management, v. 23, p. 37-44, 2003. https://doi.org/10. 1016/S0956-053X(02)00147-2

DE CORTÁZAR, A. L. G.; LANTARÓN, J. H.; FERNÁNDEZ, O. M.; MONZÓN, I. T.; LAMIA, M. F. Modelling for environmental assessment of municipal solid waste landfills (Part I: Hydrology). Waste Management \& Research, v. 20, n. 2, p. 198-210, 2002a. https://doi.org/10.1177/0734242X0202000211

DE CORTÁZAR, A. L. G.; LANTARÓN, J. H.; FERNÁNDEZ, O. M.; MONZÓN, I. T.; LAMIA, M. F. Modelling for environmental assessment of municipal solid waste landfills (Part II: Biodegradation). Waste Management \& Research, v. 20, n. 6, p. 514-528, 2002b. https://doi.org/10.1177/0734242X0202000605

DE GIOANNIS, G.; MUNTONI, A.; CAPPAI, G.; MILIA, S. Landfill gas generation after mechanical biological treatment of municipal solid waste. Estimation of gas generation rate constants. Waste Management, v. 29, n. 3, p. 1026-1034, 2009. https://doi.org/10.1016/j.wasman.2008.08.016

DI GIANFILIPPO, M.; COSTA, G.; PANTINI, S.; LOMBARDI, F.; ALLEGRINI, E.; ASTRUP, F. T. LCA of management strategies for RDF incineration and gasification bottom ash based on experimental leaching data. Waste Management, v. 47, Part B, p. 285-298, 2016a. http://dx.doi.org/10.1016/j.wasman.2015.05.032

DI GIANFILIPPO, M.; COSTA, G.; VERGINELLI, I.; GAVASCI, R.; LOMBARDI, F. Analysis and interpretation of the leaching behavior of waste thermal treatment bottom ash by batch and column tests. Waste Management, v. 56, p. 216-298, 2016b. http://dx.doi.org/10.1016/j.wasman.2016.07.034 
DI LONARDO, M. C.; GAVASCI, R.; LOMBARDI, F. Characterization of MBT plants input and outputs: a review. Reviews in environmental science and bio-technology, v. 11, p. 353-363, 2012. http://dx.doi.org/10.1007/s11157-012-9299-2

DI LONARDO, M. C.; BINNER, E.; LOMBARDI, F. Influence assessment of a lab-scale ripening process on the quality of mechanically-biologically treated MSW for possible recovery. Waste Management, v. 43, p. 50-60, 2015a. http://dx.doi.org/10.1016/j .wasman.2015.05.028

DI LONARDO, M. C.; LOMBARDI, F.; GAVASCI R. Quality evaluation and improvement of mechanically-biologically treated municipal solid waste in view of a possible recovery. International Journal of Environmental Science and Technology, v. 12, n. 10, p. 3243-3254, 2015b. http://dx.doi.org/10.1007/s13762-014-0735-4

DI LONARDO, M. C.; FRANZESE, M.; COSTA, G.; GAVASCI, R.; LOMBARDI, F. The application of SRF vs. RDF classification and specifications to the material flows of two mechanical-biological treatment plants of Rome: Comparison and implications. Waste Management, v. 47, Part B, p. 195-205, 2016. http://dx.doi.org/10.1016/j. wasman.2015.07.018

FARRELL, M.; JONES, D. L. Critical evaluation of municipal solid waste composting and potential compost markets. Bioresource Technology, v. 100, p. 4301-4310, 2009. https://doi.org/10.1016/j.biortech.2009.04.029

GRUGNALETTI, M.; VERGINELLI, I.; PANTINI, S.; LOMBARDI, F. An easy-to-use tool for the evaluation of leachate production at landfill sites. Waste Management, v. 55, p. 204-219, 2016. http://dx.doi.org/10.1016/j.wasman.2016.03.030

HJELMAR, O.; JOHNSON, A.; COMANS, R. Incineration: solid residues. In: CHRISTENSEN, T. H. (Ed.). Solid Waste Technology \& Management. Chichester: John Wiley \& Sons, 2010. http://dx.doi.org/10.1002/9780470666883.ch29

ITALIAN SUPERIOR INSTITUTE FOR ENVIRONMENTAL PROTECTION AND RESEARCH - ISPRA. Rapporto Rifiuti Urbani. Roma, 2016.

JANG, Y. S.; KIM, Y. W.; LEE, S. I. Hydraulic properties and leachate level analysis of Kimpo metropolitan landfill, Korea. Waste Management, v. 22, n. 3, p. 261-267, 2002.

LOMBARDI, F.; COSTA, G.; GAVASCI, R.; MURARO, P. MSW management strategies for the city of Rome: a comparative assessment. International Jouranl Environmental Technology and Management, v. 13, n. 3/4, p. 281-301, 2010. http://dx.doi.org/10.1504/IJETM.2010.038008

PANTINI, S.; VERGINELLI, I.; LOMBARDI, F. A new screening model for leachate production assessment at landfill sites. International Journal of Environmental Science and Technology, v. 11, n. 6, p. 1503-1516, 2014. http://dx.doi. org/10.1007/s 13762-013-0344-7

PANTINI, S.; VERGINELLI, I.; LOMBARDI, F. Analysis and modelling of metals release from MBT wastes through batch and up-flow column tests. Waste Management, v. 38, p. 22-32, 2015a. http://dx.doi.org/10.1016/j.wasman.2014.12.002 
PANTINI, S.; VERGINELLI, I.; LOMBARDI, F.; SCHEUTZ, C.; KJELDSEN, P. Assessment of biogas production from MBT waste under different operating conditions. Waste Management, v. 43, p. 37-49, 2015b. http://dx.doi.org/10.1016/j. wasman.2015.06.019

SCHROEDER, P. R.; DOZIER, T. S.; ZAPPI, P. A.; MCENROE, B. M.; SJOSTROM, J. W.; PEYTON, R. L. The hydrologic evaluation of landfill performance (HELP) model. Engineering documentation for version 3. EPA/600/R-94/168b. Cincinnati: USEPA, 1994.

VEHLOW, J.; BERGFELDT, B.; VISSER, R; WILÉN, C. European Union waste management strategy and the importance of biogenic waste. Journal of Material Cycles and Waste Management, v. 9, n. 2, p.130-139, 2007. http://dx.doi.org/10.1007/s10163-007-0178-9

VELIS, C.; WAGLAND, S.; LONGHURST, P.; POLLARD, S.; ROBSON, B.; SINFIELD, K.; WISE, S. Solid recovered fuel: influence of waste stream composition and processing on chlorine content and fuel quality. Environmental Science \& Technology, v. 46, n. 3, p. 1923-1931, 2012. http://dx.doi.org/10.1021/es2035653

YANG, N.; DAMGAARD, A.; KJELDSEN, P.; SHAO, L.-M., HE, P.-J. Quantification of regional leachate variance from municipal solid waste landfills in China. Waste Management, v. 46, p. 362-372, 2015. https://doi.org/10.1016/j.wasman.2015.09.016 